\title{
Ethnobotanical study of flora of Gulistan, district Killa Abdullah, Balochistan, Pakistan
}

Pashtana Sahib Jan ${ }^{1}$, Bibi Sadia ${ }^{*}$, Atia Yousaf ${ }^{1}$, Naila Naz ${ }^{1}$, Naseema Rehmat $^{1}$, Bibi Tahira ${ }^{1}$, Naheed Sajjad ${ }^{2}$, Shaista Hameed ${ }^{1}$ and Zahoor Ahmed Bazai ${ }^{3}$

1. Department of Botany, Sardar Bahadur Khan Women's University, Quetta, Pakistan

2. Department of Biotechnology, Sardar Bahadur Khan Women's University, Quetta, Pakistan

3. Department of Botany, University of Balochistan, Quetta, Pakistan

*Corresponding author's email: zarmal.gul@gmail.com

Citation

Pashtana Sahib Jan, Bibi Sadia, Atia Yousaf, Naila Naz, Naseema Rehmat, Bibi Tahira, Naheed Sajjad, Shaista Hameed and Zahoor Ahmed Bazai. Ethnobotanical study of flora of Gulistan, district Killa Abdullah, Balochistan, Pakistan. Pure and Applied Biology. Vol. 5, Issue 2, 2016, pp361-368. http://dx.doi.org/10.19045/bspab.2016.50047

\begin{tabular}{llll}
\hline \hline Received: 13/01/2016 & Revised: 03/03/2016 & Accepted: 25/03/2016 & Online First: 18/04/2016
\end{tabular}

\section{Abstract}

Ethnobotany is the study of diverse usage of plants by people, especially by indigenous community. Natives of Gulistan region of district Killa Abdullah, province Balochistan possess a wealthy culture and rich history of tribal society with regard to the usage of local plants. The residents use the plants for cooking, curing diseases, fuel, construction etc. This traditional knowledge has passed from generation to generation. The field survey and interview are the best ways to document their knowledge. In the present study a total of 35 wild and cultivated plants belonging to 20 families were compiled which were traditionally used by the community mostly for treatment of various ailments. Maximum number of species studied belongs to the family Rosaceae with 5 species, and the remaining families were represented by less than five species. The aims of ethnobotanical research activities in Balochistan were to provide awareness to the local community; overall global trend towards the indigenous knowledge, re-emergence and the transmission of knowledge has also been initiated. Traditional knowledge may be preserved and utilized in modern pharmaceutical industry and for conservation of plants.

Key words: Ethnobotany; Flora; Indigenous knowledge; Medicinal plants; Gulistan

\section{Introduction}

The term ethnobotany was introduced by an American botanist Johan W. Harshbergerin (1896) and it is the study of direct interaction of plant and human population [1]. The indigenous knowledge refers to the folk wisdom of the tribal and indigenous people based on accumulation of knowledge which is inherited in cultures and tribes from antiquity through trials and errors, not like other knowledge which originates in research institutes [2]. In autochthonous societies the ethnobotanical knowledge is transferred from one generation to the other via personal experiences and oral communication [3]. The importance of ethnobotanical studies in Pakistan is prevailing with the passage of time due to resurgence of different novel and incurable diseases [4]. In Pakistan out of six thousand 
plants, 600 plants have been classified as medicinal plants [5]. Up to 1950, 84\% of Pakistani was dependent on indigenous medicines for health care and also most of their daily requirements were derived from indigenous practices, but now these are practiced only in specific remote areas [6]. Balochistan covers about $44 \%$ of the land area of Pakistan and is the largest province which is blessed with diverse fauna and flora along with versatile ecological conditions [7]. In the southern west areas of Balochistan 114 plant species were used for having, medicinal properties [8]. In Balochistan the elderly women were observed to be an expert for usage of indigenous plants, as they knew the techniques of treatment for number of different ailments $[9,10]$. The use of medicinal plants by local community against different diseases were as; jaundice, toothache, typhoid, kidney pain, hair fall, joints pain, edema, purification of blood, pimples, chest infections, insects and snake bites, high blood pressure, and diabetes [11]. Study conducted in protected area of Hingol National Park (Lasbela District, Balochistan) revealed that 39 plant species were used as remedies for different ailments by local people [12]. The present study was carried out to explore the ethnobotanical knowledge of flora of Gulistan, district Killa Abdullah, Balochistan.

\section{Materials and Methods Study area}

District Killa Abdullah is the $6^{\text {th }}$ smallest district in Balochistan with an area of 3,293 $\mathrm{km}^{2}$. It lies between $66^{\circ} 14^{\prime} 23^{\prime \prime}-67^{\circ} 15^{\prime} 43^{\prime \prime}$ east longitudes and $30^{\circ} 05^{\prime} 7^{\prime \prime}-31^{\circ} 18^{\prime} 46^{\prime \prime}$ north latitudes and consist of four Tehsils (Chaman, Dobandi, Gulistan and killa Abdullah) and 25 Union Councils (Figure 1). Killa Abdullah is located at $690 \mathrm{~km}$ south-west of Pakistan's Capital City Islamabad and $70 \mathrm{~km}$ north from Quetta city (provincial capital of Balochistan). The climate of district Killa Abdullah is generally dry and temperate. The district lies outside the sphere of monsoon currents, so rainfall is irregular and insufficient. The climatic conditions of the district are particularly suitable for horticulture and agriculture, and especially suitable for the growth of fruits e.g. apples, apricots, peaches, plums, grapes, cherries and vegetables such as potatoes, onions and tomatoes [13].

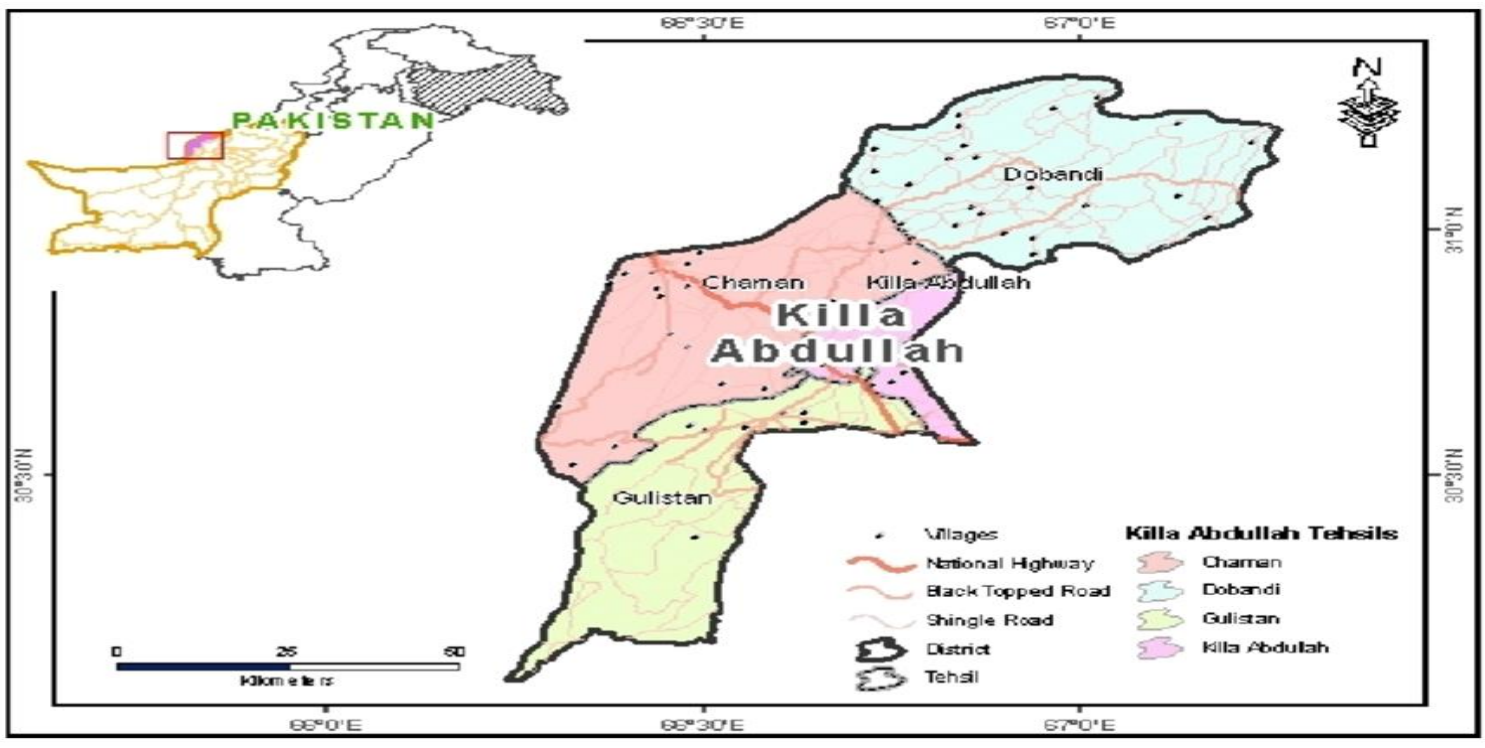

Figure 1. Map of Pakistan showing Killa Abdullah Balochistan (District development profile, 2011) 


\section{Data collection}

The study was carried out during the months of June-July 2014. The survey questionnaire was designed to collect data based on the knowledge of indigenous communities of the area for usage of different parts of plant species. About 100 informants of different age groups were selected randomly for interview (ranged between 18-80 years old). Majority of the informants were female due to their acquaintance to usage of medicinal plants rather than male. The plant samples were collected from different areas of the district and identification of these plant species was carried out with the help of flora of Pakistan [14-16]. The plants were arranged according to their local names, families, part used and their respective usage by local communities [17].

\section{Results}

A total of 35 wild and cultivated plants belonging to 20 families were culled commonly used by the local communities of studied area for different purposes such as food, medicines and fodder for animals, fuel, construction and agriculture (Table 1). The dominating family was Rosaceae with 5 species, followed by Apiaceae with 4 species, Lamiaceae and Asteraceae with 3 species each, Amaryllidaceae, Cruciferae and Fabaceae respectively with 2 species each and the remaining families were represented by one species each.

Table 1. Detailed taxonomic account of plants with local name and indigenous usage

\begin{tabular}{|c|c|c|c|c|c|}
\hline Botanical names & Local names & Family & Habits & Part uses & Uses \\
\hline Allium griffithianum & Piyaz & Amaryllidaceae & Herb & Whole plant & $\begin{array}{l}\text { Use as food, also used for treatment of } \\
\text { jaundice. } \\
\text { Bulb is heated and used for wounds and to } \\
\text { treat pus. }\end{array}$ \\
\hline Allium sativum & Wozha & Amaryllidaceae & Herb & Whole plant & $\begin{array}{l}\text { Raw garlic is used to reduce arterial blood } \\
\text { pressure and for treatment of diabetes. }\end{array}$ \\
\hline Amaranthus viridis & Sarmakae & Amaranthaceae & Herb & Whole plant & Cook as vegetable. \\
\hline Avena sativa & Jawari & Poaceae & Shrub & Whole plant & Fodder, seeds used for eating purpose. \\
\hline Berbaris densifolia & Korha & Berberidaceae & Herb & Whole plant & Used as a fuel. \\
\hline Cardaria pubescens & Bushki & $\begin{array}{l}\text { Cruciferae } \\
\text { (Brassicaceae) }\end{array}$ & Herb & Whole plant & Cooking purpose. \\
\hline Carthamus tenius & Kondalie & Asteraceae & Herb & Whole plant & $\begin{array}{l}\text { Plant is soaked in water and then drink to } \\
\text { treat fever, also used for mosquitos' } \\
\text { expulsion. }\end{array}$ \\
\hline Cerepedium quettens & Tarkha & Asteraceae & Herb & Whole plant & $\begin{array}{l}\text { Green leaves of plant are soaked or boiled } \\
\text { in water for treatment of diabetes and for } \\
\text { treatment of malaria fever. Used as fodder. } \\
\text { Dried plant is used as fuel. }\end{array}$ \\
\hline Cousinia thomsonii & Zoaz & Asteraceae & Herb & Whole plant & $\begin{array}{l}\text { Used as fodder for animal. Used as a fuel, } \\
\text { also used for roofing of huts. }\end{array}$ \\
\hline Cuminum cyminum & Speena zeera & Apiaceae & Herb & Seeds & $\begin{array}{l}\text { Used for treatment of urinary tract infection, } \\
\text { warm effect, gastric disorder. Used by } \\
\text { breast feeding mother to increase lactation. } \\
\text { Used as condiment in cooking. }\end{array}$ \\
\hline
\end{tabular}




\begin{tabular}{|c|c|c|c|c|c|}
\hline Ephedra intermedia & Oman & Ephedraceae & Herb & Whole plant & $\begin{array}{l}\text { Stem is used as antiseptic, also used for } \\
\text { relief of cough and healing of wounds. Plant } \\
\text { is boiled in water and steam is given to the } \\
\text { patients of pneumonia. }\end{array}$ \\
\hline $\begin{array}{l}\text { Eucalyptus } \\
\text { sideroxylon }\end{array}$ & Walye & Myrtaceae & Tree & Whole plant & Used for fire purposes and roofing. \\
\hline Ficus carica & Inzer & Moraceae & Tree & Fruits & $\begin{array}{l}\text { Used as food, Dry fruits of fig boiled with } \\
\text { milk and used for treatment of cough and } \\
\text { liver problems. }\end{array}$ \\
\hline Foeniculum vulgare & $\begin{array}{l}\text { Khozha } \\
\text { wallani }\end{array}$ & $\begin{array}{l}\text { Apiaceae } \\
\text { (Umbelliferae) }\end{array}$ & Shrub & Seeds & $\begin{array}{l}\text { Used for gastric disorder. Decoction with } \\
\text { other herbs is used for treatment of } \\
\text { abdominal pain in children. }\end{array}$ \\
\hline Heloxylon griffithii & Shorie & Chenopodiaceae & Herb & Whole plant & Used as fuel. \\
\hline Medicago sativa & Shpishtie & Fabaceae & Herb & Whole plant & $\begin{array}{l}\text { Used as fodder, cultivated dried plant is also } \\
\text { used as fodder in winter. }\end{array}$ \\
\hline Mentha longifolia & Shinshobie & Lamiaceae & Herb & Whole plant & $\begin{array}{l}\text { Used to treat flu and have anti allergic } \\
\text { effect / taken with yogurt to produce } \\
\text { cooling effect. }\end{array}$ \\
\hline Mentha spicuta & Nana & Lamiaceae & Herb & Whole plant & $\begin{array}{l}\text { Boil in water \& cooled it and drink early in } \\
\text { the morning to produce cooling effect in } \\
\text { stomach. }\end{array}$ \\
\hline Papaver somniferum & Taryak & Papaveraceae & Herb & $\begin{array}{l}\text { Seeds, } \\
\text { receptacle } \\
\text { and latex }\end{array}$ & $\begin{array}{l}\text { Receptacle of poppy is boil in water and } \\
\text { used for cough and seeds mixed with sugar } \\
\text { syrup is used for relief of children. Seeds } \\
\text { soaked in water overnight than grinded with } \\
\text { almonds mixed with milk and drink for } \\
\text { cooling purposes. }\end{array}$ \\
\hline Peganum hermala & Spallanae & Zygophyllaceae & Herb & $\begin{array}{l}\text { Seed / leaves } \\
\text { and branches }\end{array}$ & $\begin{array}{l}\text { Seeds taken with water for gastric problems } \\
\text { and heart burning. }\end{array}$ \\
\hline Phaseolus vulgaris & Lobia & Fabaceae & Herb & Seeds & For cooking purpose \\
\hline Plantago major & Bartang & Plantaginaceae & Herb & Seeds & $\begin{array}{l}\text { Produce warm effect, seeds are cooked with } \\
\text { water and sugar to treat flu and } \\
\text { constipation. In combination with } \\
\text { Trachespermum it is used to treat cough and } \\
\text { bronchial problems. }\end{array}$ \\
\hline $\begin{array}{l}\text { Polygonum } \\
\text { arenastrum }\end{array}$ & Zomae & Polygonaceae & Herb & Whole plant & $\begin{array}{l}\text { Used as a fodder for animal, hut roofing/ as } \\
\text { a fuel / used for floor compaction. }\end{array}$ \\
\hline Portulaca oleraceae & Khulfa & Portulacaceae & Herb & $\begin{array}{l}\text { Whole plant } \\
\text { without roots }\end{array}$ & Cooked as vegetable. \\
\hline Prunus cultivar & Santroza & Rosaceae & Tree & Fruits & $\begin{array}{l}\text { Eating purpose, Ash is used to fertilize the } \\
\text { land. }\end{array}$ \\
\hline Prunus domestica & Plum & Rosaceae & Tree & Fruits & $\begin{array}{l}\text { Eating purpose, Ash is used to fertilize the } \\
\text { land. }\end{array}$ \\
\hline Prunus persica & Zardaloo & Rosaceae & Tree & $\begin{array}{l}\text { Fruits, leaves } \\
\text { and branches }\end{array}$ & $\begin{array}{l}\text { Leaves are used for fodder, Branches are } \\
\text { used for fuel purposes and roofing, fruits } \\
\text { are used for eating, Ash is used to fertilize } \\
\text { the land. }\end{array}$ \\
\hline Punica granatum & Anar & Lythraceae & Tree & Fruits, seeds & $\begin{array}{l}\text { Used as fruit. Dried Peel is grinded and } \\
\text { mixed with yogurt to treat dysentery. }\end{array}$ \\
\hline
\end{tabular}




\begin{tabular}{|c|c|c|c|c|c|}
\hline Pyrus malus & Saib & Rosaceae & Tree & Fruits & $\begin{array}{l}\text { Eating purpose, Ash is used to fertilize the } \\
\text { land. }\end{array}$ \\
\hline Rosa indica & Gulgulap & Rosaceae & Shrub & $\begin{array}{l}\text { Mostly } \\
\text { flowers }\end{array}$ & $\begin{array}{l}\text { It has a cooling effect used in combination } \\
\text { with other herbs to treat constipation and } \\
\text { other gastric problems. Flowers of plants } \\
\text { soaked in water to make gulkand. Rose } \\
\text { water is used for clearing of eyes. }\end{array}$ \\
\hline $\begin{array}{l}\text { Tamarixindica var. } \\
\text { galica }\end{array}$ & Ghza & Tamariaceae & Shrub & Whole plant & Used as fuel and for thatching and roofing. \\
\hline $\begin{array}{l}\text { Teucrium } \\
\text { stocksianum } \\
\text { var. incanum }\end{array}$ & Kalpora & Lamiaceae & Herb & Whole plant & Soak in water and drink for fever. \\
\hline $\begin{array}{l}\text { Trachespermum } \\
\text { ammi }\end{array}$ & Spareki & Apiaceae & Herb & $\begin{array}{l}\text { Mostly seeds } \\
\text { are used }\end{array}$ & $\begin{array}{l}\text { Produce warm effect. Used to cure liver } \\
\text { disorder, lung, gastric disorder and for } \\
\text { fever. }\end{array}$ \\
\hline Sisymbrium irio & Khaksheer & $\begin{array}{l}\text { Cruciferae } \\
\text { (Brassicaceae) }\end{array}$ & Herb & Seeds & $\begin{array}{l}\text { Produce cooling effect to treat stomach } \\
\text { disorder, constipation. Also used for } \\
\text { abdominal pain. }\end{array}$ \\
\hline Zosima absinthifolia & Zonkaie & Apiaceae & Herb & Whole plant & Use as salad. \\
\hline
\end{tabular}

\section{Discussion}

Pakistan has been blessed with a variety of medicinal plants due to its diverse climatic conditions [18]. Balochistan province due to its inaccessibility and isolation for centuries provides sanctuary for indigenous habitat of some herbal plants. The present study revealed that for majority of population of the studied areas, the whole plant used $(51 \%)$ followed by seeds $(23 \%)$, Fruits (15\%), leaves/branches (5\%) and flowers/receptacle and latex $(3 \%)$ for the cure of different ailments (Figure $2 \& 3$ ).

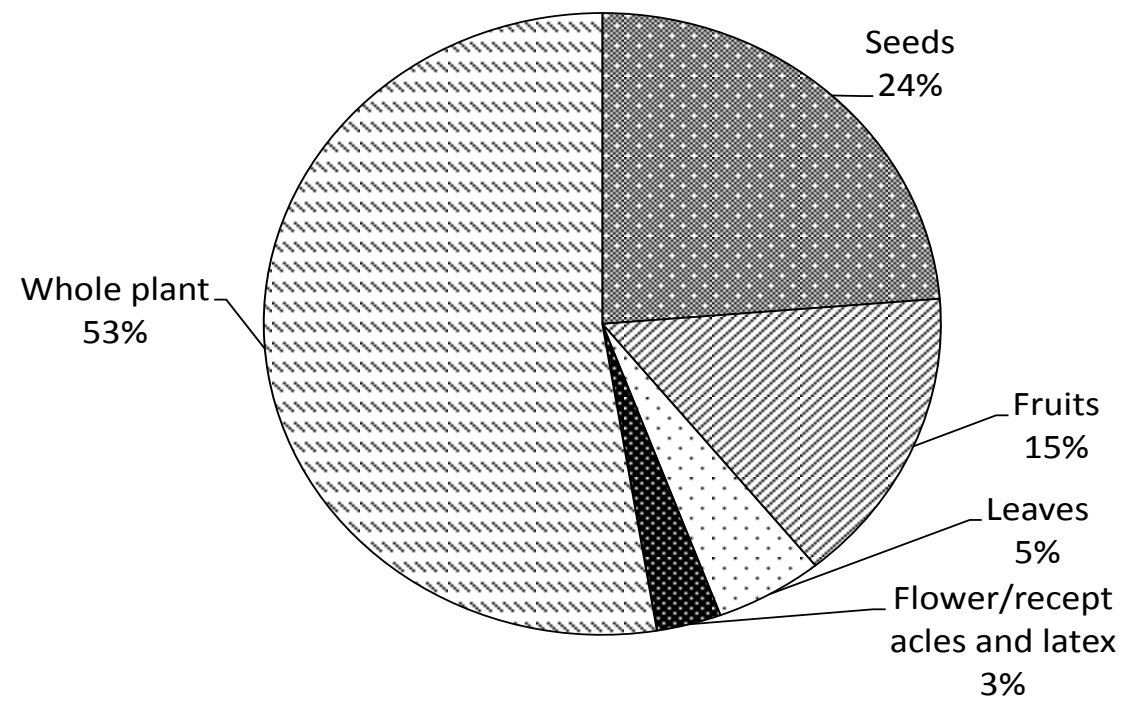

Figure 2. Percentage of plant parts for multiple uses 
The extract of Punica granatum is used for vomiting, nausea and for stomach upsets [19]. In Gulistan district, the fruits of this plant were used as food and dried peel has been grinded and mixed with yogurt to treat dysentery. The plant parts such as leaves and seeds of Peganum hermalaare used for the treatment of asthma, cough, leg pain, gastric problem and heart diseases $[20,21]$. Studies carried out in Kalat and Khuzdar areas revealed that the root extracts of Berberis balochistanica has been used for injury and joint pain. However, the women folks of
Killa Abdullah used decoction of the seeds of the same plant for flu, cough and bronchial disorders [22]. Similarly in Kalat and Khuzdar the seed extracts of Zosimia absinthifolia has been used to treat the thirst of children and throat problems while the local people of Gulistan used the leaves of this plant species as crouton.

The seeds of Cuminum cyminum were used for sanative of urinary tract infection, warm effect, and gastric disorder and also used by breast feeding mother to increase lactation [23].

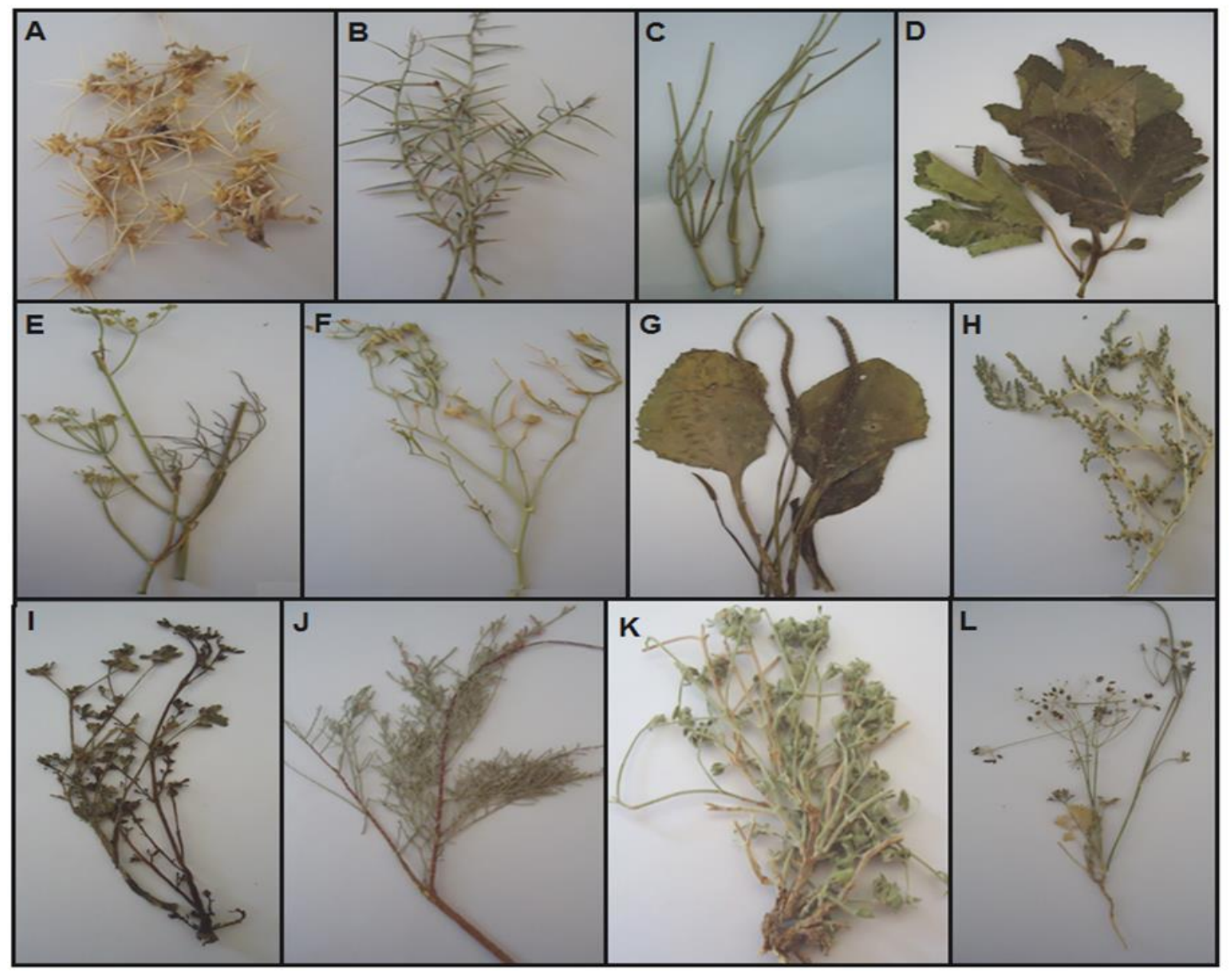

Figure 3. Some examples of medicinal plants collected from studied areas of Balochistan (A: Carthamus tenius, B: Cousinia thomsonii, C: Ephedra intermedia, D: Ficus carica, E: Foeniculum vulgare, F: Peganum hermala, G: Plantago major, H: Polygonum arenastrum, I: Portulaca oleraceae, J: Tamarix indica var. galica, K: Teucrium stocksianum, L: Zosima absinthifolia) 


\section{Conclusions}

It is concluded that Gulistan area has been observed as rich in its indigenous knowledge for the use of local plants. The plants were used for various purposes like treatment of diseases, fuel and construction. The plant species can be utilized for uplifting the economic constrains of the study area when utilized in a proper manner and can be commercialized to provide benefits to the local community and also to other concern groups. The traditional knowledge of local plant species help to explore new avenues for researchers to study these important plants and investigate them. For sustainable usage and long term conservation of natural resources of the study area, it is opt to carry out frequent surveys and the consent of local people in evaluation, planning, implementation and monitoring process. The consumption of medicinal plants would raise the importance of the local industry and will also reduce the expenditure incurred on the purchase of foreign drugs.

\section{Authors' contributions}

Conceived and designed the experiments: PS Jan, B Sadia \& N Sajjad, Performed the experiments: PS Jan \& A Yousaf, Analyzed the data: PS Jan, B Sadia \& B Tahira, Contributed reagents/ materials/ analysis tools: PS Jan, B Sadia, N Naz, S Hameed \& $\mathrm{N}$ Rehmat, Wrote the paper: PS Jan, ZA Bazai \& B Sadia.

\section{References}

1. Pei S (1995). Ethnobotany and sustainable use of plant resources in the $\mathrm{HKH}$ mountain region, planning workshop on ethnobotany and its application to conservation and community development in the Hindu Kush Himalayan (HKH) region Nepal.

2. Niazi AR (2011). Enhancing the role of indigenous knowledge for sustainable development. The News, weekly Business Review, 07-03-2011.
3. Shinwari ZK (2010). Medicinal plants research in Pakistan. $J$ Med Plants Res 4(3):161-176.

4. Bhatti GR, Qureshi R, \& Shah M (2001). Ethnobotany of Qadanwari of Nara Desert. Pak. J. Bot, 33:801-812.

5. Hamayun, M (2003). Ethnobotanical studies of some useful shrubs and trees of District Buner, NWFP, Pakistan. J Ethnobotanical Leaflets.

6. Ibrar M, Hussain F, \& Sultan A (2007). Ethnobotanical studies on plant resources of Ranyal hills, District Shangla, Pakistan. Pak J Bot 39(2): 329.

7. Tareen RB, Bibi T, Khan MA, Ahmad M, \& Zafar M (2010). Indigenous knowledge of folk medicine by the women of Kalat and Khuzdar regions of Balochistan, Pakistan. Pak J Bot 42(3): 1465-1485.

8. Goodman SM, \& Ghafoor A (1992). The Ethnobotany of southern Balochistan, Pakistan, with particular reference to medicinal plants. Fieldiana: Botany New Series 31(1):1-84.

9. Baloch MA (1998). The Pahwal: A Description of Nomadic life, Institulo Italiano per Medioed Estremo Oriente (ISMEO). Rome, News Letters of Baluchistan Studies 5: 23-31.

10. Dashti N (2008). The cultural context of health: A Baloch Perspective, Balochi Academy, Quetta, 80-137.

11. Baloch MP, Marri MY, \& Qaisrani MA (2013). Plants treasures, traditional knowdege and Baloch society. Balochistan Rev 28(1): 1810-2174.

12. Qureshi R (2012). Medicinal flora of Hingol National park, Baluchistan, Pakistan. Pak J Bot 44(2): 725-732.

13. District development profile of Killa Abdullah (2011). Planning and development department Government of Balochistan Quetta in collaboration with UNICEF. 
14. Ali SI \& Nasir YJ (1990-1991) (fascicles series 191-192). Flora of Pakistan, Karachi.

15. Qureshi R (2004). Floristic and Ethnobotanical Study of Desert Nara Region, Sindh. Department of Botany, Shah Abdul Latif University, Khairpur, Sindh, Pakistan. Ph.D. Thesis. 1: 1300.

16. Ali SI, \& Qaiser M (Eds.) (1993-2008). Flora of Pakistan, Karachi.

17. Hussain AN, Ali IQ, Ashraf MA \& Haider MZ (2013). Ethnobotanical studies of potential wild medicinal plants of Ormara, Gawadar, Pakistan. Emir J Food Agric 25(10): 751-759.

18. Chaudari II (1961). Distribution of some important medicinal plants of West Pakistan. Pakistan J Sci Ind Res 4:207-211.

19. Khan MA, Khan A, Mujtaba G \& Hussain M (2012). Ethnobotanical study about medicinal plants of poonch valley Azad kashmir. J Anim Plant Sci 22(2): 493-500.

20. Abbasi AM, Dastagir G, Hussain F, \& Sanaullah P (2005). Ethnobotany and marketing of crude drug plants in district Haripur, Pakistan. Pak J Plant Sci 11(2): 103-114.

21. Hussain K, Shahazad A, \& Zia-ulHussnain S (2008). An ethnobotanical survey of important wild medicinal plants of Hattar district Haripur, Pakistan. Ethnobotanical Leaflets 12(1): 5.

22. Tareen RB, Bibi T, Khan MA, Ahmad M, \& Zafar M (2010). Indigenous knowledge of folk medicine by the women of Kalat and Khuzdar regions of Balochistan, Pakistan. Pak J Bot 42(3): 1465-1485.

23. Chittora M, Tiwari K (2013). Biology and Biotechnology of Cumin. Int $J$ Bioassays 2(7): 1066-1068. 